\title{
E-kitabxanalarda Tətbiq Olunan Proqram Vasitələrinin Analizi: Üstünlükləri və Çatışmazlıqları
}

\author{
Firudin Osgərov \\ AMEA İnformasiya Texnologiyaları İnstitutu, Bakı, Azərbaycan \\ firudinasgarov@gmail.com
}

\begin{abstract}
Xülasə - Məqalədə elektron kitabxanalarda tətbiq olunmuş Kitabxana İdarəetmə Sistemlərinin təhlili verilmişdir. Müxtəlif ölkələrin istehsalı olan Alephino, Destiny, Millenium, IRBIS-64, Virtua, Alexandria, Resource Mate və s. Kitabxana İdarəetmə Sistemlərinin üstünlükləri və çatışmazlıqları göstərilmişdir.
\end{abstract}

Açar sözlor- elektron kitabxana, kitabxana idaraetmo sistemi, proqram tominat, Z39.50, SIP2, MARC-21

\section{GİRISS}

Kitabxana konsepsiyası yarandı̆̆ı vaxtdan bu günə kimi insanların informasiya tələbatının ödənilməsi və informasiyanın gələcək nəsillərə ötürülməsi funksiyasını yerinə yetirir. Hazırda kitabxanalar vətəndaş cəmiyyətinin əsas göstəricisi olan qlobal informasiya mühitinin, beynəlxalq, milli və regional səviyyədə informasiya mübadiləsi sistemlərinin yaradılmasında, informasiyanın әmtəəуə çevrilməsində aparıcı rol oynayır.

Dünya təcrübəsi göstərir ki, kitabxanaların avtomatlaşdırılması - yüksək ixtisaslı kitabxanaçıların və proqramçıların birgə fəaliyyətinin nəticəsi kimi informasiya kommunikasiya texnologiyalarının (IKT) tətbiqi ilə həyata keçirilən mürəkkəb məsələlərdən biridir. Qeyd edək ki, kitabxana proseslərinin kompleks şəkildə avtomatlaşdırılması Kitabxana İnformasiya Sistemlərinin yaradılmasını nəzərdə tutur. Kitabxana İnformasiya Sistemlərinin yaradılmasının əsas məqsədlərindən biri informasiyanın sürətlə artdığ 1 və yeniləndiyi bir şəraitdə, İKT imkanlarından istifadə etməklə yerləşdiyi məkandan və zamandan asılı olmayaraq kitabxanalar, oxucular arasında informasiya mübadiləsinin həyata keçirilməsi və istifadəçi sorğularına operativ münasibət bildirilməsidir.

Hələ 1971-ci ildə kitabxana-informasiya sahəsində dünyada aparıcı mütəxəssislərdən hesab olunan X.X.Bernşteyn kitabxananın avtomatlaşdırılması üçün bir neçə prinsip irəli sürmüşdür $\mathrm{ki}$, bunlardan biri də proqram təminatıdır [1].

Avtomatlaşdırma prosesini həyata keçirmək üçün ilkin olaraq proqram təminatı seçilməlidir. Seçim zamanı İKT bazarında mövcud proqram təminatı analiz olunmalı və onun içərisindən ən optimalı müəyyən olunmalıdır. Kitabxana proseslərini kompleks avtomatlaşdırmaq üçün yaradılmış

Tətbiqi Proqram Paketləri bir çox hallarda Avtomatlaşmış Kitabxana İnformasiya Sistemləri (KİS) adlandırılır. Halhazırda daha çox inkişaf etmiş ölkələrdə Avtomatlaşmış
Kitabxana İnformasiya sistemləri Kitabxana İdarəetmə Sistemləri adlanır. Müasir tələblərə cavab verən Kitabxana İdarəetmə Sistemləri biblioqrafik metaverilənlərin maşınla oxuna bilməsi üçün MARC-21 (MAchine-Readable Cataloging) standartını, kitabxanalararası biblioqrafik informasiya mübadiləsini həyata keçirmək üçün Z39.50 protokolunu (International standard client-server, application layer communications protocol), kitabxana daxilində oxucuların self-check aparatları vasitəsi ilə kitabxanaçının köməyi olmadan informasiya resursunun əldə olunub, geri qaytarılmasını təmin etmək üçün SIP2 (Standard Interchange Protocol - Standart Mübadilə Protokolu) protokolunu dəstəkləməlidir [2].

İş e-kitabxanalarda istifadə olunan kitabxana idarəetmə sistemlərinin təhlilinə həsr olunmuşdur. Kitabxana idarəetmə sistemlərinin proqram təminatının üstünlükləri və çatışmazlıqları müqayisəli araşdırılır.

\section{MÖVCUD KİTABXANA İDARӘETMӘ SISTEMLORININ ÜSTÜNLÜKLӘRİ VӘ ÇATIŞMAZLIQLARI}

Müasir dövrdə dünyada çoxlu sayda müxtəlif ölkələrin istehsalı olan KİS-lər vardır. Bu KİS-lərə Alephino, Destiny, Millenium, IRBIS-64, Virtua, Alexandria, ResourceMate və s. nümunə göstərmək olar [3].

Onların üstün və zəif cəhətlərinə görə aşağıdakı kimi təsnif etmək olar.

Alephino proqram təminatı Exlibris şirkəti tərəfindən yaradılmışdır. Şirkətin əsası 1986-c1 ildə İsraildə qoyulub. Dünyanın 90 ölkəsində 6000-dən çox istifadəçisi var.

- Üstün cəhətləri: SIP2 və Z39.50 protokolunun dəstəklənməsi, Azərbaycan dilində biblioqrafik metaverilənlərin daxil edilməsi mümkünlüyü, rəqəmsal yaddaşın (Digital repository) yaradılması imkanı.

- Mənfi cəhətləri: İşçilər üçün nəzərdə tutulan modullardan istifadəyə qoyulan giriş limitləri, həmçinin oxucuların informasiya resurslarını onlayn rejimdə axtarması üçün nəzərdə tutulan web OPAC-dan (Online Public Access Catalog) istifadəyə qoyulan giriş limitləri. Tətbiq edilən limitlər proqram paketlərinin qiymətlərinə görə dəyişir [4]

Alexandria proqram təminatı 1987-ci ildə COMPanion korporasiyası tərəfindən ABŞ-da yaradılmışdır. Dünyada 1000-dən çox kitabxanada tətbiq olunur. Üstün cəhətləri: Demo (pulsuz) versiyasının olmas1. SIP2 və Z39.50 protokolunun dəstəklənməsi. Sadə interfeysə malik olması. 
Mənfi cəhətləri: Yalnız latin qrafikasının dəstəklənməsi. Azərbaycan dilində biblioqrafik metaverilənlərin daxil edilməsi mümkün deyil [5].

Destiny (Follett) Follett korporasiyası 1873-cü ildə ABŞda yaradılmışdır (kitab mağazası olaraq). 1985-ci ildə Follett proqram təminatı şirkəti qurulub və 2003-cü ildə özünün Destiny adlı kitabxana idarə sistemini hazırlamışdır. Dünyada 1300-dən çox kitabxanada tətbiq olunur.

$\checkmark$ Üstün cəhətləri: Z39.50 protokolunun dəstəklənməsi. Azərbaycan dilində biblioqrafik metaverilənlərin daxil edilməsi mümkünlüyü.

$\checkmark$ Mənfi cəhətləri: SIP2 protokolunun dəstəklənməməsi [6].

İRBİS-64 Rusiya istehsalı olan bu proqram təminatı ELNIT assosiasiyası tərəfindən işlənib hazırlanmıșdır. Dünyanın 20-yə yaxın ölkəsində 1500-dən çox kitabxanasında tətbiq olunur. 2005-ci ildən etibarən Azərbaycan Milli Elmlər

Akademiyası Mərkəzi Elmi Kitabxanası da daxil olmaqla Azərbaycanda bir neçə kitabxanada tətbiq olunmağa başlanıb [7].

$\checkmark$ Üstün cəhətləri: Demo (pulsuz) versiyasının olmas1. Z39.50 və SIP2 protokolunun dəstəklənməsi. Azərbaycan dilində biblioqrafik metaverilənlərin daxil edilməsi mümkünlüyü.

$\checkmark$ Mənfi cəhətləri: Sistemin rus dilində olması (məhdud dairədə yayılıb, istifadə olunur). Proqram təminatının qiymət baxımından Avropa və qərb ölkələrinin əksər proqram təminatları ilə təxminən eyni olmasına baxmayaraq texniki və digər çətinliklərin dəstəklənməsində problemlər [8]

Millenium proqram təminatı Innovative Interfaces şirkəti (1978 - Berkeley, California, USA) tərəfindən 1990-cı illərdə hazırlanmışdır. Hal-hazırda 1300-dən çox kitabxanada tətbiq olunur.

$\checkmark$ Üstün cəhətləri: SIP2 və Z39.50 protokolunun dəstəklənməsi. Azərbaycan dilində biblioqrafik metaverilənlərin daxil edilməsi mümkünlüyü.

$\checkmark \quad$ Mənfi cəhətləri: Qiymətinin çox yüksək olması [9].

ResourceMate proqram təminatı Kanada istehsalıdır. 1993-cü ildə Jaywil Software Development korporasiyası tərəfindən yaradılıb.

$\checkmark$ Müsbət cəhətləri: Demo (pulsuz) versiyasının olması. Sip2 protokolunun dəstəklənməsi. Qiymətinin digər sistemlərə nisbətən ucuz olmas1.

$\checkmark$ Mənfi cəhətləri: Z39.50 protokolunun dəstəklənməməsi. Kiçik həcmli kitabxanalar üçün nəzərdə tutulmasi [10].

Virtua (VTLS) Virtua KİS 1998-ci ildə VTLS şirkəti (1985- Blacksburg, Virginia, USA) tərəfindən yaradılmışdır. $\mathrm{Bu}$ şirkət 2014-cü ildə Innovative Interfaces şirkəti tərəfindən alınmışdır. $\checkmark$ Müsbət cəhətləri: SIP2 və Z39.50 protokolunun dəstəklənməsi. Azərbaycan dilində biblioqrafik metaverilənlərin daxil edilməsi mümkünlüyü.

$\checkmark$ Mənfi cəhətləri: Bu kitabxana idarəetmə sistemində də Alephino, Millenium və s. qərb ölkələri istehsalı olan KİS-lərdə olduğu kimi oxucular haqqında statistik məlumatların əlçatan olmaması problemidir. Həmçinin bəzi ölkələrə məxsus simvolları sistemə daxil etmək mümkün deyil [11].

Qeyd etmək lazımdır ki, müasir kitabxana idarəetmə sistemi özündə bütün ənənəvi kitabxana proseslərini əhatə etməlidir. KIS-in Circulation (dövriyyə), Cataloging (kataloqlaşdırma),Acquisitions (komplektləşdirmə), Serials (dövri nəșrlər) və s. modulları bu işləri həyat keçirir. Təhlillər göstərir ki, qiymətinin baha olmasına baxmayaraq böyük kitabxanalarda Millenium KİS, kiçik kitabxanalarda isə Alephino KİS tətbiq etmək daha əlverişlidir.

Bunlardan əlavə elektron kitabxanaların elmmetrik qiymətləndirmələr, həmçinin böyük verilənlər üçün informasiya mənbəyi rolu oynadığına görə uyğun modulların yaradılmasina ehtiyac var.

\section{NӘTİCə}

Hazırda kitabxana-informasiya mühitində kitabxanaçıların və oxucuların tələblərinə cavab verən Kitabxana İdarəetmə Sisteminin seçilməsi ən vacib məsələlərdən biridir. Məqalədə elektron kitabxanalarda tatbiq olunan proqram təminatlarının müqayisəli analizi həyata keçirilmiş, Kitabxana İdarəetmə Sistemlərinin üstünlükləri və çatışmazlıqları göstərilmişdir. Kitabxana ișinin yüksək səviyyədə təşkili və KİS-lərin təkmilləşdirilməsi üçün təkliflər irəli sürülmüşdür.

\section{ӘDӘBIYYAT}

[1] N.N.Musayeva, M.S.Xəlilov, A.İ.Qurbanov. Kitabxana informatikası: dərs vəsaiti, 2-ci cild, elmi red. İ.Đ.Qurbanov.-B.:Odlar yurdu, 2002.$164 \mathrm{~s}$

[2] C.Cəfərov. Kitabxana-informasiya xidmətində elektron kataloq. Bak1: Proqres, 2012, 224 s.

[3] www.capterra.com/library-automation-software/

[4] ex-lh.hu/site/index.php/en/alephino-4-eng

[5] www.goalexandria.com/

[6] www.follettlearning.com/technology/products/library-managementsystem

[7] S.M.Mustafayeva. Azərbaycan Milli Elmlər Akademiyası Mərkəzi Elmi Kitabxanasında elektron kataloqun təşkili və inkişaf perspektivləri //Kitabxanaşünaslıq və Biblioqrafiya, 2012, № 1, s. 44-54.

[8] www.elnit.org/index.php?option=com_content\&view=article\&id=35\&It emid $=108$

[9] www.iii.com/products/millenium-ils/

[10] www.resourcemate.com/

[11] www.iii.com/products/virtua-ils/ 